\title{
Susceptibility-weighted imaging in Todd paralysis
}

Figure MRI manifestations of hemispheric hypoperfusion in a patient with Todd paralysis

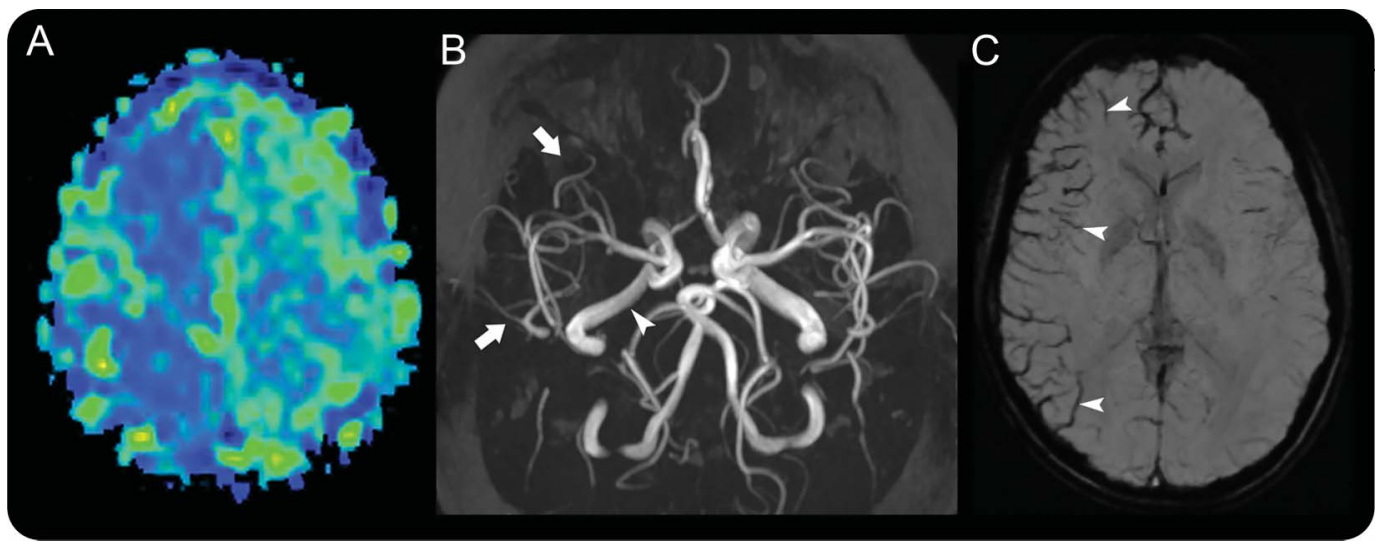

Arterial spin labeling (A) shows marked hypoperfusion in the right cerebral hemisphere. There is decreased caliber of the right internal carotid artery $(B$, arrowhead) and paucity of right middle cerebral artery branches ( $B$, arrows) on magnetic resonance angiography. Susceptibility-weighted imaging shows prominent hypointensity within right-sided cortical draining veins (C, arrowheads).

A 10-year-old boy presented with left hemiplegia and facial droop after prolonged seizure activity overnight. MRI showed hypoperfusion involving the right cerebral hemisphere. Susceptibility-weighted imaging (SWI) demonstrated prominence of ipsilateral draining veins, indicating increased deoxyhemoglobin content within the hypoperfused territory (figure). ${ }^{1}$ There was no acute infarct. Weakness improved over several hours and the patient was discharged after returning to baseline. While the pathophysiology of Todd paralysis remains elusive, prior reports have documented reversible hypoperfusion. ${ }^{2} \mathrm{SWI}$ is a robust and relatively novel imaging technique that is highly sensitive to deoxyhemoglobin and can be an adjunct in the evaluation of perfusion abnormalities.

\section{Carlos A. Zamora, MD, PhD, Marinos Kontzialis, $M D$}

From the Johns Hopkins University School of Medicine, Baltimore, MD.

Author contributions: Carlos Zamora: study concept, analysis of MR imaging data, drafting and revising the manuscript, final approval. Marinos Kontzialis: analysis of MR imaging data, revising the manuscript, final approval.

Study funding: No targeted funding reported.

Disclosure: The authors report no disclosures relevant to the manuscript. Go to Neurology.org for full disclosures.

Correspondence to Dr. Zamora: czamora2@jhmi.edu

1. Mittal S, Wu Z, Neelavalli J, Haacke EM. Susceptibility-weighted imaging: technical aspects and clinical applications, part 2. AJNR Am J Neuroradiol 2009;30:232-252.

2. Rupprecht S, Schwab M, Fitzek C, Witte OW, Terborg C, Hagemann G. Hemispheric hypoperfusion in postictal paresis mimics early brain ischemia. Epilepsy Res 2010;89:355-359. 


\section{Neurology}

\section{Susceptibility-weighted imaging in Todd paralysis}

Carlos A. Zamora and Marinos Kontzialis

Neurology 2015;85;297

DOI 10.1212/WNL.0000000000001770

This information is current as of July 20, 2015

\section{Updated Information \& Services}

References

Subspecialty Collections

Permissions \& Licensing

Reprints including high resolution figures, can be found at: http://n.neurology.org/content/85/3/297.full

This article cites 2 articles, 1 of which you can access for free at: http://n.neurology.org/content/85/3/297.full\#ref-list-1

This article, along with others on similar topics, appears in the following collection(s):

All Epilepsy/Seizures

http://n.neurology.org/cgi/collection/all_epilepsy_seizures

MRI

http://n.neurology.org/cgi/collection/mri

Status epilepticus

http://n.neurology.org/cgi/collection/status_epilepticus

Information about reproducing this article in parts (figures,tables) or in its entirety can be found online at:

http://www.neurology.org/about/about_the_journal\#permissions

Information about ordering reprints can be found online:

http://n.neurology.org/subscribers/advertise

Neurology ${ }^{\circledR}$ is the official journal of the American Academy of Neurology. Published continuously since 1951, it is now a weekly with 48 issues per year. Copyright @ 2015 American Academy of Neurology. All rights reserved. Print ISSN: 0028-3878. Online ISSN: 1526-632X.

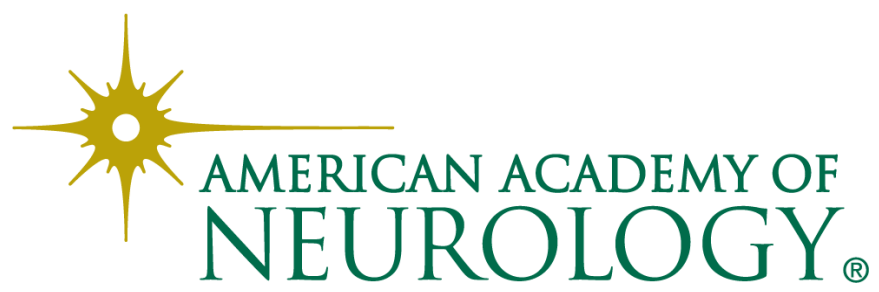

